\title{
Students' learning autonomy, involvement and motivation towards their English proficiency
}

\author{
Hoang Yen Phuong* \& Phuong Quyen Vo \\ School of Foreign Languages, Can Tho University \\ *Corresponding Author \\ Email: phyen@ctu.edu.vn
}

\begin{abstract}
Different factors are involved in the process of learners' learning English as a second or foreign language. Among them, learning autonomy, involvement and motivation and attitude toward English language learning have been claimed to positively correlate with learners' English proficiency. In the current study, 229 English-majored final-year students at a university in Vietnam were invited to participate in a survey to explore their English proficiency level and factors that may have impacted that level. Findings revealed that students' learning autonomy and their active participation in classroom activities are the most influential on their English proficiency level after four years of learning. As a result, the study suggests that measures should be taken to improve students' learning autonomy and classroom involvement.
\end{abstract}

Keywords: EFL learners, influencing factors, English proficiency
Received:
Revised:
Accepted:
Published:
15 November 201825 January 2019
28 February 2019
28 February 2019

\section{INTRODUCTION}

Since English has become an international language, the number of learners learning English as a second or foreign language increases day by day. A report by the British Council for the years 2017-2018 says that there are 750 million English as a foreign language speakers and 375 million English as a second language learners worldwide (British Council, 2018). In Vietnam, English learning and teaching has been the focus of attention of the government since 2008 with the launch of Vietnam National Foreign Language Project accompanying the Decision 1400/QD-TTg issued on September 30, 2008.

One of the main goals of the project is "most young Vietnamese graduates of professional secondary schools, colleges and universities will have a good command of foreign language which enables them to independently and confidently communicate" (Vietnam Prime Minister, 2008). However, after nearly a decade since its inception, the project has been criticized for falling behind many of its initial targets for 2020 (Phuong, 2017), one of which is that learners of English in Vietnam may have been influenced by different factors which interfere in their process of gaining the expected English language proficiency. Up to now, few studies have been conducted to 
explore these influential factors in a Vietnamese context, which is the gap that the current study aims to fill.

The current study seeks to answer the following research question:

To what extent learner autonomy, learning involvement and learning motivation impact English-majored students' English proficiency level?

Students' learning autonomy can be considered as one of the crucial factors affecting their level of proficiency in English language. As Hedge (2000, p.410) explained, autonomy is "the ability of the learner to take responsibility for his or her own learning, and to plan, organize, monitor the learning process independently of the teacher". Sharing the same concern, Little (2007) emphasizes that autonomous learners are aware of their strengths and weaknesses, so they are motivated to be responsible for their own learning. The author further implies that the more the level of learner autonomy is enhanced, the more the growth of learners' target language proficiency is achieved. In other words, students' learning autonomy is implied as an inevitably existing contributor to the level of English learners' proficiency.

Followed by this concern, several studies have proved a close-knit relationship between students' learning autonomy and their level of English language proficiency. In particular, Dafei (2007) explores the relationship between autonomy and English language proficiency learners revealed by 129 non-English majored students in a teacher college in China by means of a questionnaire and an interview. The result showed a significant and positive differences between two variables. This means that learners' autonomy was the same as their English proficiency was not different and that these learners' level of proficiency showed differences resulted in the significant differences in their autonomy. Additionally, Nguyen (2008) studied the relationship between learner autonomy and Vietnamese English-majored students' English language proficiency. She studied seventy seven English majors from a university in Vietnam and used related questionnaires for this purpose. The internal examination results was then included. Based on the results, Nguyen has found positive and significant correlations between most aspects of learner autonomy and EFL proficiency measures.

Explained more specifically, particular aspects of students' learning autonomy have been clarified such as having an intrinsic interest in English, trying hard to use English out of class, and being able to plan, monitor, and evaluate their own learning. These aspects are concluded as main contributors to students' success in English language achievement. In the context of Iran, Hashemian and Soureshjani (2011) investigates the interrelationship of autonomy, motivation, and academic performance. The study was conducted with 60 Persian learners. Two questionnaires, one for autonomy and one for motivation, were deployed to gather the required data. The data was then analysed through correlation and regression. The bivariate correlation reported a significant correlation between learner autonomy and academic performance. Similar implications have also been found in studies by Mohamadpour (2013) to explore the autonomy level of 30 senior high school students in Tehran by means of a questionnaire and interview and their English proficiency using PET. The data were analyzed by T-test with SPSS 16.0. The results showed that the correlation coefficient indicates that 
learners' autonomy and the English proficiency of the participants are positively correlated $(0.402)$. The study concluded that the more proficient an English language learner is, the more autonomous they would be. Another study by Myartawan, Latief, and Suharmanto (2013) is aimed to determine the correlation between learner autonomy and English proficiency of 120 student participants selected by using a proportionate sampling technique from a population of 171 first semester students of the English Education Department, Ganesha University of Education (Undiksha) in Bali, Indonesia. The data were obtained from documents and questionnaires. In this study, the multiple linear regression analysis conducted revealed that learner autonomy and English proficiency as defined in the study had a significant, strong, positive relationship. It is clearly stated that students' learning autonomy and their language proficiency are closely interrelated.

\section{Learner learning involvement and EP}

Learner learning involvement has been also considered to be another correlating factor to students' EP. In particular, the involvement of learners in learning can be identified as learner classroom participation. As Hamzah, Hilmi and Thivya (2016) mention, student classroom involvement can be seen as an important factor affecting students' language learning process, so students who actively participate in classroom activities are likely to get their language achievement better than those with poor participation. Related to this concern, the study by Fakeye and Amao (2013) investigated the extent to which classroom participation and study habits predicted students' academic achievement in Literature-in-English in selected senior secondary school in Ibadan North Local Government Area of Oyo State. The findings further indicated that classroom participation was the only variable that predicted students' achievement in Literature in English. Focusing on English speaking skill class, the study by Carhill, Suárez-Orozco, \& Páez (2008) with 247 immigrant students of English as a second language in the United States share the same implication that that the amount of time students spent speaking English in class can be considered as an influential predictor to their English language proficiency.

Another factor related to learner learning involvement is their self-study time. This can be implied as autonomy in language use by learners (Little, 2007). Sharing the same concern, the study by Nguyen (2008) examines the relationships between learner autonomy and EFL proficiency in a Vietnamese university context with 177 English-majored students and the findings indicated that there were strong correlations between using English out of class and language learning proficiency. This can be implied that learning English out of class or students' self-study time is likely to go hand in hand with students' achieving their language learning outcomes.

The involvement in English environment is mentioned as another contributor to students' EP. As Latu (1994) stated, the amount and kind of exposure to the target language are vital for language learners to develop their learning language, so they cannot perform the target language well once they do not the environment to practice it (Musa, Lie, \& Azman, 2012). In other words, students learning foreign languages may face certain challenges as they lack the access to the environment to practice the target language 
(Ganapathy \& Ying, 2016). As a consequence, students' involvement in English speaking environment may allow them more opportunities to enhance their language proficiency.

Learner learning motivations and attitude toward English learning and EP Another factor contributing to the level of proficiency in English among students is related to their motivation and attitudes to English language learning (Brown, 2007; Ellis, 1994, Gardner \& Lambert, 1972; Holmes, 2017; Littlewood, 1984; Spolsky, 1969). As Gardner and Lambert (1972) clarify, students with high level of motivation grounded in positive attitudes toward the second language will be successful in second language learning while students with negative attitudes are related to learners' anxiousness, making them unsuccessful in second language acquisition. Based on Brown's (2007, p.114) definition of motivation which is "an inner drive impulse, emotion or desire that moves one to a particular action and motivation is a task-oriented", Daskalovska, Gudeva, and Ivanovska (2012) further add that a motivated language learner desires to achieve learning goals and willingly spends time and effort reaching that goal, so learners' motivation to learn the language can be considered as one of the most important factors enhancing their language proficiency.

Having experimentally worked on the learning motivation and attitudes and the language proficiency, researchers have explored the tangible relationship between students' motivation and attitude and their English language proficiency. For example, a study in Turkey by İnal, Evin, and Saracaloğlu (2003) was conducted with four hundred and twenty one students from different school contexts. The findings showed that students' attitudes toward English language received a higher positive correlation with their learning achievement compared to other variables such as high school type, second language, medium of instruction, parents' education, living abroad. In another context, Eun-Hee and Hee Jeong (2011) investigate ninety-two firstyear Korean university students who took a mandatory English course by a means of a questionnaire on their motivation to learn English and answered short essay questions related to their preferences in English courses. Data analysis indicated that means for students' interest was the sole factor contributing to the participants' scores improvement.

A study by Al-Mahrooqi1 (2012) employing a qualitative questionnaire with focus groups and personal reports from 100 tertiary education students revealed that lacking motivation in English learning can be considered as one major factor leading students' low English language proficiency. With more focus on learning practice, a study by Thanh and Huan (2012) explore the role of task-based learning in motivating non-English major Vietnamese students to enhance their vocabulary learning. The results showed the influential role of text-based tasks in student' motivation and their vocabulary learning improvement.

With the focus on clarifying the relationships of both motivation and attitude and English language proficiency, Liu (2007) investigates Chinese university students' attitudes and motivation to learn English and the correlations of both variables with the students' English proficiency. The study conducted with 202 Chinese third-year English non-majored students and adapted the motivation survey by Gardner (1985) and an English proficiency 
test. The finding from the correlation analysis revealed that the students with more positive attitudes towards learning English tended to score higher in the proficiency test and those who were more instrumentally motivated tended to perform better in the test. Liu emphasizes these factors contributed to the result of students' higher English proficiency. Followed the same research instrument by a questionnaire survey on attitudes and motivation adapted Gardner's (1985) Attitude and Motivation Test Battery, Thang, Ting, and Nurjanah 's (2011) study was undertaken with 143 Chinese, Malay and Iban students from both Science and Art classes in East Malaysia studying English as a second language. The data were analysed using the descriptive correlation coefficient and ANOVA inferential tools. The study revealed that the better students had more positive attitudes and showed greater initiatives towards learning English than the weak students. However, students' extrinsic motivation was perceived as a more influential factor for students to learn English than their intrinsic motivation. Despite such the fact, the study showed a positive relationship between higher proficiency level and positive attitudes and motivation to learn English. Sharing the same vein, a recent study by Phon (2017) investigate the relationship between students' English proficiency levels with three variables, namely socioeconomic status, learning motivations and attitudes, and learning opportunities. The study employed a set of questionnaires adapted from the general theory of language learning of Spolsky's (1989) model with fifteen English-majored students at a rural public university in Cambodia. The data was then analysed by Spearman's correlation and the findings indicated that students' motivation and learning attitude had a strong correlation with students' English language proficiency level compared to other variables. As consequence, students' motivation and attitudes play a vital role to improve students' proficiency in English language, or students of second language must have both motivation and attitude to achieve their success in language proficiency.

In summary, students' language proficiency can be considerably affected by various student-related factors, namely learner autonomy, learner learning involvement, and learner learning motivations and attitude toward English learning. This can be considered as a theoretical framework for the current study to examine the extent to which these factors have affected students' language proficiency in the context of a Vietnamese university. Additionally, the review of such factors will support the findings of the current study in terms of identifying differences and similarities with the existing literatures as well as contributing to the body of literatures related to factors influencing students' language proficiency in English as a second language.

\section{METHOD}

\section{The participants}

The target population of the current study was 229 final year students of English language programs in a Vietnamese university. Of the student participants, nearly two thirds (74\%) came from the city, compared to $26 \%$ of them from the country. Among them, 189 of students (83\%) major in English Language, followed by 29 of them (13\%) majoring in English Translation and Interpretation, and 11 of those studying English Teaching, accounting for 4\%. The number of male and female students were 58 and 171 respectively. 
Participants' ages range from 19 to 21 . The participants were selected as the study sample on a voluntary basis. The selection of sample based on the purposive sampling approach, which is a process of selecting a sample that is believed to represent a given population (Cohen, Manion, \& Morrison, 2013).

\section{The questionnaire}

The data were collected through a 5-point Likert-type scale survey questionnaire. Its main design was to discover factors influencing students' language proficiency. The questionnaire had two main sections. The first section contained some questions asking the participants about their demographic information including their name, gender, major. The second section was designed to uncover the factors affecting students' performance with three primary clusters including learners' autonomy, learners' learning involvement, and learners' motivations and attitude toward English learning.

In the questionnaire, students' learning autonomy was investigated through the 8 items in Section 2.1. Students' learning involvement was explored through questions asking about their self-study time, their class attendance, their time for part-time job and whether their job has anything to do with English in Section 2.2. For Section 2.3, motivation consists of two clusters namely intrinsic motivation and extrinsic motivation. The researcher used a 5-point Likert scale to indicate frequency from "never" to "always" on learning autonomy and involvement, and from "totally wrong" to "totally right" to items on learner motivation.

\section{RESULT AND DISCUSSION}

\section{Impact of learner learning autonomy on their EP}

The impact of learner learning autonomy on their English proficiency is measured by calculating the correlations between their current English proficiency and the 8 items in the questionnaire. In this study, students were asked to state their English proficiency level basing on the scores of the English standardized tests that they had taken in the past few years. For those who do not possess these scores, a description of the language proficiency levels according to the Common European Framework of Reference for Languages (CEFR) was listed in the questionnaire. The three levels listed include B1, B2 and C1. These three levels were listed because according to the Vietnamese Qualifications Framework, students who majored in English are expected to reach $\mathrm{C} 1$ level at the time of their graduation. Level B1, B2 and C1 are coded as 1, 2 and 3 respectively in the statistic tests. 
Table 1: Correlation Matrix (observed variables) of students' EP and various

\begin{tabular}{|c|c|c|c|c|c|c|c|c|c|c|c|}
\hline Variables & Mean & SD & 1 & 2 & 3 & 4 & 5 & 6 & 7 & 8 & 9 \\
\hline $\begin{array}{l}\text { 1. English language } \\
\text { proficiency }\end{array}$ & 1.46 & .66 & 1.0 & & & & & & & & \\
\hline $\begin{array}{l}2 . \text { I have adapted } \\
\text { well with the } \\
\text { requirements in the } \\
\text { study program. }\end{array}$ & 3.92 & .61 & $.16^{*}$ & 1.0 & & & & & & & \\
\hline $\begin{array}{l}\text { 3. I have been able } \\
\text { to manage my time } \\
\text { easily. }\end{array}$ & 3.57 & .74 & $.22^{* *}$ & $.44 * *$ & 1.0 & & & & & & \\
\hline $\begin{array}{l}\text { 4. I have studied } \\
\text { hard in my study } \\
\text { program. }\end{array}$ & 3.90 & .75 & $.13^{*}$ & $.27^{* *}$ & $.29 * *$ & 1.0 & & & & & \\
\hline $\begin{array}{l}\text { 5. I have been able } \\
\text { to choose how I } \\
\text { want to learn. }\end{array}$ & 3.80 & .76 & .04 & $.31^{* *}$ & $.20^{* *}$ & $.23^{* *}$ & 1.0 & & & & \\
\hline $\begin{array}{l}\text { 6. I know my } \\
\text { learning style and } \\
\text { use it effectively. }\end{array}$ & 3.62 & .77 & $.25^{* *}$ & $.35^{* *}$ & $.49 * *$ & $.23^{* *}$ & $.34 * *$ & 1.0 & & & \\
\hline $\begin{array}{l}\text { 7. I self-study } \\
\text { because I am } \\
\text { interested in } \\
\text { learning English } \\
\text { language and skills. }\end{array}$ & 3.90 & .76 & $.28^{* *}$ & $.29 * *$ & $.27 * *$ & $.27^{* *}$ & $.20 * *$ & $.46^{* *}$ & 1.0 & & \\
\hline $\begin{array}{l}\text { 8. I have always } \\
\text { looked for better } \\
\text { ways of learning. }\end{array}$ & 3.92 & .76 & $.14^{*}$ & $.14^{*}$ & $.23^{* *}$ & $.33^{* *}$ & $.17^{*}$ & $.28^{* *}$ & $.43^{* *}$ & 1.0 & \\
\hline $\begin{array}{l}\text { 9. I always have } \\
\text { new and creative } \\
\text { ideas when } \\
\text { learning. }\end{array}$ & 3.36 & .73 & $.17^{*}$ & $.31^{* *}$ & $.25^{* *}$ & $.19 * *$ & $.20 * *$ & $.41^{* *}$ & $.31^{* *}$ & $.31^{* *}$ & 1.0 \\
\hline
\end{tabular}

Data analyses reveal that most of the student participants $(61 \%)$ possessed B1 level at the time of the study. Less than one tenth of them had C1 level while 31\% gained B2 level.

Correlation tests show that learner English proficiency is positively correlated with seven out of eight items in the section asking about their learning autonomy (see Table 1).

The highest correlations were found between English learner proficiency and three following specific aspects of learner autonomy. First and foremost, students' self-study was weakly but significantly correlated with their EP ( $r=$ .28, $n=229, p<.001)$. In addition, there were statistically significant correlations between learners' EP and the fact that they know their learning style and use it effectively and that they are able to manage their time easily ( $r$ $=.25, n=229, p<.001$ and $r=.2, n=229, p<.001$ respectively).

Four other aspects correlating with learner EP are Item 9, Item 8, Item 2 and Item 4 with the Pearson correlation coefficients range from $r=.14$ to $r=$ .17 and the $\mathrm{p}$ values of $.01, .02, .03$ and .04 respectively.

There was no correlation between learners' EP and whether they have been able to choose how they want to learn.

The findings in the current study are in line with what Dafei (2007), Nguyen (2008), Hashemian and Soureshjani (2011) and Mohamadpour (2013) found in their studies. In other words, the higher level of autonomy learners possess, the higher English proficiency they achieve. Therefore, measures should be taken to enhance learners' autonomy if they want to improve their English proficiency. Focus of these measurements should be on learners' time management, self-study, and effective exploitation of one's own learning style. 
Phuong \& Vo, EduLite: Journal of English Education, Literature, and Culture Vol.4, No.1, February 2019,

\section{Impact of learner learning involvement in terms of time and effort on their EP}

Learners' involvement in term of time are measured via the three questions asking for students' daily self-study time, classroom attendance and time for part-time job. Pearson product-moment correlations were run to determine the relationship between students' EP and time investment. Results reveal that among the three categories of time investment, only time spent on attending class has a positive correlation with students' EP $(r=.20, n=229, p=.003)$. Daily self-study time and time for part-time job do not correlate with students' EP.

The findings are similar to those in the study by Carhill et al. (2008), Fakeye and Amao (2013, and Hamzah et al. (2016). In other words, students' EP levels are impacted by the time they spend in the classroom. More time spent, higher proficiency gained. However, the current study reveals different findings with what Nguyen (2014) found in his study. The EP level of the student participants in the current study has no correlation with the time they spend on self-study outside the classroom.

A Pearson product-moment correlation was run to determine the relationship between students' effort and EP. There was a positive correlation between them, which was statistically significant $(r=.19, n=14, p=.004)$. The impact of specific learners' efforts on their EP are shown in Table 2 below.

Table 2: Correlation Matrix (observed variables) of students' EP and their involvement in term of efforts

\begin{tabular}{|c|c|c|c|c|c|c|c|c|c|c|c|c|c|}
\hline Variables & Mean & SD & 1 & 2 & 3 & 4 & 5 & 6 & 7 & 8 & 9 & 10 & 11 \\
\hline $\begin{array}{l}\text { 1. English language } \\
\text { proficiency }\end{array}$ & 1.46 & .66 & 1.0 & & & & & & & & & & \\
\hline $\begin{array}{l}\text { 2. I pay attention when } \\
\text { my teachers are } \\
\text { teaching. }\end{array}$ & 4.08 & .63 & .12 & 1.0 & & & & & & & & & \\
\hline $\begin{array}{l}\text { 3. I learn in groups with } \\
\text { my friends outside the } \\
\text { classroom. }\end{array}$ & 3.15 & .69 & .05 & $.13^{*}$ & 1.0 & & & & & & & & \\
\hline $\begin{array}{l}\text { 4. I listen/watch } \\
\text { English clips on online } \\
\text { channels like Youtube, } \\
\text { Ellen Show and so on. }\end{array}$ & 3.80 & .72 & $.26 * *$ & .07 & $.16^{*}$ & 1.0 & & & & & & & \\
\hline $\begin{array}{l}\text { 5. I discuss in English } \\
\text { with my friends in the } \\
\text { classroom. }\end{array}$ & 3.34 & .79 & .07 & $.31^{* *}$ & $.35^{* *}$ & $.16^{*}$ & 1.0 & & & & & & \\
\hline $\begin{array}{l}\text { 6. I learn English on } \\
\text { different websites on the } \\
\text { internet. }\end{array}$ & 3.39 & .87 & .03 & .07 & $.13^{*}$ & $.28^{* *}$ & $.31^{* *}$ & 1.0 & & & & & \\
\hline $\begin{array}{l}\text { 7. I practice my English } \\
\text { writing skills. }\end{array}$ & 3.35 & .86 & .09 & .09 & $.30 * *$ & $.22^{* *}$ & .26 & $.27^{* *}$ & 1.0 & & & & \\
\hline $\begin{array}{l}\text { 8. I read English texts } \\
\text { given in the teaching } \\
\text { materials. }\end{array}$ & 4.00 & .71 & .09 & $.16^{*}$ & $.22^{* *}$ & $.23^{* *}$ & $.29 * *$ & $.18^{* *}$ & $.36^{* *}$ & 1.0 & & & \\
\hline $\begin{array}{l}\text { 9. I make oral } \\
\text { presentations in front of } \\
\text { my class. }\end{array}$ & 3.99 & .76 & $.16^{*}$ & $.25^{* *}$ & $.21^{* *}$ & $.28^{* *}$ & $.31^{* *}$ & .08 & .10 & $.36^{* *}$ & 1.0 & & \\
\hline $\begin{array}{l}\text { 10. I read English books } \\
\text { and newspapers. }\end{array}$ & 3.22 & .78 & $.34 * *$ & $.18^{* *}$ & $.14^{*}$ & $.37 * *$ & $.21^{* *}$ & $.22^{* *}$ & $.27^{* *}$ & $.29 * *$ & $.17^{* *}$ & 1.0 & \\
\hline $\begin{array}{l}11 . \text { I learn outside the } \\
\text { classroom with the } \\
\text { materials not given by } \\
\text { my teachers. }\end{array}$ & 3.17 & .79 & $.28 * *$ & .09 & $.19 * *$ & $.31^{* *}$ & $.26^{* *}$ & $.34 * *$ & $.28^{* *}$ & $.33^{* *}$ & $.26^{* *}$ & $.38 * *$ & 1.0 \\
\hline
\end{tabular}


Among various efforts that students made, only four ones have significantly positive correlations with their EP. The strongest correlation is found between students' extensive reading (Item 10) and their $\operatorname{EP}(r=.34, n=$ 229, $p<.001)$. The second strongest correlation is between students' EP and their learning outside the classroom with the materials not given by the teachers (Item 11) $(r=.28, n=229, p<.001)$. The other two correlations are between students' EP and their watching and listening to clips on different channels on the internet (Item 4) as well as and oral presentations they made in class $(r=.26, n=229, p<.001$ and $r=.16, n=229, p=.02$ respectively).

These findings correspond to those in the studies by Latu (1994) and Nguyen (2014). In other words, the more investments students have on learning with other learning resources outside the classroom, the higher proficiency they possess.

\section{Impact of learner learning motivation and attitude toward English language learning on EP}

Two types of motivation have been investigated in the current study. Regarding intrinsic motivation, there was no correlation in the overall intrinsic motivation and EP. However, there was a positive correlation between students' EP and one type of intrinsic motivation (see Table 3).

Table 3: Correlation Matrix (observed variables) of students' EP and their intrinsic motivation

\begin{tabular}{|c|c|c|c|c|c|c|c|c|}
\hline Variables & Mean & SD & 1 & 2 & 3 & 4 & 5 & 6 \\
\hline 1. English proficiency & 1.46 & .66 & 1.0 & & & & & \\
\hline $\begin{array}{l}\text { 2. In general, I find English } \\
\text { courses in the study program } \\
\text { interesting. }\end{array}$ & 3.13 & .90 & -.05 & 1.0 & & & & \\
\hline $\begin{array}{l}\text { 3. In general, I only try to } \\
\text { finish the requirements in the } \\
\text { study program. }\end{array}$ & 3.49 & .90 & -.06 & -.31 & 1.0 & & & \\
\hline $\begin{array}{l}\text { 4. I am interested in learning } \\
\text { new knowledge in English } \\
\text { courses of the study program. }\end{array}$ & 3.66 & .82 & .09 & $.15^{*}$ & -.11 & 1.0 & & \\
\hline $\begin{array}{l}\text { 5. I feel satisfied with being } \\
\text { intellectually challenged and } \\
\text { pressured to overcome } \\
\text { different obstacles to improve } \\
\text { my English proficiency. }\end{array}$ & 3.77 & .83 & $.22^{* *}$ & -.07 & .03 & $.35^{* *}$ & 1.0 & \\
\hline $\begin{array}{l}\text { 6. In general, I like the English } \\
\text { subjects in the study program. }\end{array}$ & 3.38 & .78 & .07 & $.47 * *$ & -.06 & $.57 *$ & $.30^{* *}$ & 1.0 \\
\hline
\end{tabular}

The positive correlation found is between students' EP and their feeling of satisfaction with being intellectually challenged and pressured to overcome different obstacles to improve my English proficiency (Item 5$),(r=.22, n=229$, $p<.001)$.

With regard to extrinsic motivation, there were no correlations between students' EP and overall extrinsic motivation as well as between students' EP and specific aspects of extrinsic motivation (see Table 4). 
Phuong \& Vo, EduLite: Journal of English Education, Literature, and Culture Vol.4, No.1, February 2019,

Table 4: Correlation Matrix (observed variables) of students' EP and their

\begin{tabular}{|c|c|c|c|c|c|c|c|}
\hline Variables & Mean & SD & 1 & 2 & 3 & 4 & 5 \\
\hline $\begin{array}{l}\text { 1. English language } \\
\text { proficiency }\end{array}$ & 1.46 & .66 & 1.0 & & & & \\
\hline $\begin{array}{l}\text { 2. I only want to learn courses } \\
\text { that serve my future jobs. }\end{array}$ & 3.47 & 1.07 & .04 & 1.0 & & & \\
\hline $\begin{array}{l}\text { 3. I only want to get high } \\
\text { marks. }\end{array}$ & 3.31 & 1.00 & -.08 & -.00 & 1.0 & & \\
\hline $\begin{array}{l}\text { 4. I need to know how well I } \\
\text { learn so that I have } \\
\text { motivation to learn more. }\end{array}$ & 3.83 & .76 & -.07 & -.06 & $.26^{* *}$ & 1.0 & \\
\hline $\begin{array}{l}\text { 5. In general, English teachers } \\
\text { in the study program make } \\
\text { me interested in learning } \\
\text { English. }\end{array}$ & 3.21 & .91 & -.02 & $.27^{* *}$ & $\begin{array}{c}- \\
18^{* *}\end{array}$ & .06 & 1.0 \\
\hline
\end{tabular}

In short, motivation plays a role in deciding whether English language learners can achieve their expected English proficiency or not. However, in the current study, only intrinsic motivation positively correlated with students' EP. Such findings were dissimilar with those in the study by Nurjanah (2011).

\section{CONCLUSION AND RECOMMENDATIONS}

The current study explores the impact of students' learning autonomy, learning involvement and motivation on their English proficiency levels. Findings reveal that specific aspects in each factor play a role in helping students to achieve their current English proficiency. Therefore, teachers in similar contexts of the current study should figure out measures to enhance these specific aspects of their learners' learning autonomy, involvement and motivation. Such measures will be more cost-effective as compared to investing in improving students' overall learner autonomy, involvement or motivation if teachers want to focus on improving their students' English proficiency.

\section{REFERENCES}

Al-Mahrooqi1 R. (2012). A student perspective on low English proficiency in Oman. International Education Studies, 5 (6): 236-271. Available at http://www.ccsenet.org/journal/index.php/ies/article/view/19832

British Council (2018). Annual report and account 2017-2018. Available at https://www.britishcouncil.org/sites/default/files/2017-18-annualreport.pdf

Brown, D. (2007). Principles of language learning and teaching, Fifth Edition. White Plain, NY: Pearson Longman, 410 pages.

Carhill, A., Suárez-Orozco, C., \& Páez, M. (2008). Explaining English language proficiency among adolescent immigrant students. American Educational Research Journal, 45(4), 1155-1179.

Dafei, D. (2007). An exploration of the relationship between learner autonomy and English proficiency. In P. Robertson, P. \& R. Nunn (Eds.), Asian EFL Journal: Teaching Articles 2007. Busan: Asian EFL Journal Press, pp.1-23.

Daskalovska, N., Gudeva, L. K., Ivanovska, B. (2012). Learner motivation and interest. Social and Behavioral Sciences, 46: 1187-1191. 
Ellis, R., (1994). The study of second language acquisition. Oxford: Oxford University Press, 824 pages.

Eun-Hee, L. \& Hee Jeong, O. (2011). Relationship between motivation and proficiency improvement. Linguistic Research, 28(2): 405-430. Available at http://isli.khu.ac.kr/journal/content/data/28_2/9.pdf

Fakeye, D. O. \& Amao, T. A. (2013). Classroom participation and study habit as predictors of achievement in Literature-in-English. Cross-Cultural Communication, 9 (3), 18-25. Available at http://www.cscanada.net/index.php/ccc/article/view/j.ccc.192367002 0130903.2741

Ganapathy, M., \& Ying, G. C. (2016). Attitude and motivation of students towards learning English as second language in a secondary school in Penang. Malaysian Journal of Languages and Linguistics (MJLL), 5(2), 39-56.

Gardner, R.C. (1985). Social psychology and second language learning: The role of attitudes and motivation. London: Edward Arnold, 208 pages.

Gardner, R.; W. Lambert. (1972). Attitudes and motivation in second language learning. Rowley, Massachusetts: Newsbury House, 313 pages.

Hamzah, Mohd Hilmi \& Asokan, Thivya. (2016). The Effect of Participation Instruction on ESL Students' Speaking Skills and Language Anxiety. International Conference of Higher Order Thinking Skills 2016 in Conjunction with $2^{\text {nd }}$ International Seminar on Science and Mathematics Education 2016. Available https://www.researchgate.net/publication/303334588_The_Effect_of_Parti cipation_Instruction_on_ESL_Students'_Speaking_Skills_and_Language_An xiety

Hashemian, M., \& Soureshjani, K. H. (2011). The interrelationship of autonomy, motivation, and academic performance of Persian L2 learners in distance education contexts. Theory and Practice in Language Studies, 1(4), 319-326.

Hassan, F., Selamat, N. F., (2002). Why aren't students proficient in ESL: The Teachers' perspective. The English Teacher. 31: 107-123. Available from https://journals.melta.org.my/index.php/tet/article/view/362/252

Hedge, T. (2000). Teaching and learning in the language classroom. Oxford: Oxford University Press. 448 pages.

Holmes, J. \& Wilson, N. (2017). An introduction to sociolinguistics. Routledge.

İnal, S. , Evin, İ., \& Saracaloğlu, A. S. (2003). The relation between students' attitudes toward foreign language and foreign language achievement. Dil Dergisi, 130: 38-53.

Latu, M. F. (1994). Factors affecting the learning of English as a second language macroskills among Tongan secondary students. Unpublished Master of Arts thesis: Edith Cowan University, Australia.

Little, D. (2007). Language learner autonomy: Some fundamental considerations revisited. Innovation in language learning and teaching, $1(1): 14-29$.

Littlewood, W. (1984). Foreign and second language learning: Language acquisition research and its implications for the classroom. Cambridge University Press.

Liu, M. (2007). Chinese students' motivation to learn English at the tertiary level. Asian EFL Journal. 9 (1): 126-146. Available at 
Phuong \& Vo, EduLite: Journal of English Education, Literature, and Culture Vol.4, No.1, February 2019,

https:/ /www.asian-efl-journal.com/1042/quarterly-journal/chinesestudents-motivation-to-learn-english-at-the-tertiary-level/

Mohamadpour, P. (2013). Realization of autonomy and English language proficiency among Iranian high school students. Theory and Practice in Language Studies, 3 (7): 1187-1193.

Myartawan, I. ; Latief, M.; Suharmanto. (2013). The correlation between learner autonomy and English proficiency of Indonesian EFL college learners. TEFLIN Journal, 24 (1): 63-81. https://www.researchgate.net/publication/259762858

Musa, N. C., Lie, K. Y., \& Azman, H. (2012). Exploring English language learning and teaching in Malaysia. GEMA Online ${ }^{\circledR}$ Journal of Language Studies, 12(1).

Nguyen, T.C. L. (2008). Learner autonomy and EFL proficiency: A Vietnamese perspective. Asian Journal of English Language Teaching, 18: 67-87.

Phon, S. (2017). Factors affecting the English language proficiency of students majoring in English at a rural university in Cambodia. UC Occasional Paper Series, 1(1): 69-92.

Phuong, H. Y. (2017). Improving English language teaching in Vietnam: Voices from university teachers and students. In Shimura, Y. (Ed.) The people of Vietnam: Their voices and lived experiences. Pages 91-120. Nova Science Publisher: New York.

Spolsky, B. (1989). Conditions for second language learning: Introduction to a general theory. Oxford: Oxford University Press, 272 pages.

Thanh, L. N., \& Huan, N. B. (2012). Task-Based Language Learning and Student Motivation in Vocabulary Acquisition. Language Education in Asia, 3(1): 106-120.

Thang S. M., Ting S. L., Nurjanah M. J., (2011). Attitudes and motivation of Malaysian secondary students towards learning English as a second language: A case study. The Southeast Asian Journal of English Language Studies 17(1): 40 - 54. Available at http://journalarticle.ukm.my/2047/1/5._3LVol17(1)2011Thang_Siew_ Ming_et_al_doc.pdf

Vietnam Prime Minister (2008). Decision 1400/QD-TTg on approving the scheme on foreign language teaching and learning in the national education system in the 2008-2020 period. Available at https://thuvienphapluat.vn/archive/Quyetdinh/1400-QD-TTgvb83815t17.aspx 